\title{
Implementation of Interactive Multimedia and Kit with Writing-to-Learn Strategy on the Chemistry in Daily Life Topic for Junior High School with Disabilities
}

\author{
Sukarmin ${ }^{1}$, Sri Poedjiastoeti ${ }^{2}$, Dian Novita $^{3}$, Achmad Lutfi $^{4}$, Luky Susanti $^{5}$ \\ \{ sukarmin@unesa.ac.id ${ }^{1}$, sripoedjiastoeti@unesa.ac.id ${ }^{2}$, diannovita@unesa.ac.id ${ }^{3}$, \\ achmadlutfi@unesa.ac.id ${ }^{4}$, lukysusanti@mhs.unesa.ac.id $\left.{ }^{5}\right\}$
}

Chemistry, Faculty of Mathematics and Science, Universitas Negeri Surabaya, Indonesia ${ }^{1,2,3,4}$, Science Education, Postgraduate, Universitas Negeri Surabaya, Indonesia ${ }^{5}$

\begin{abstract}
This study goals to describe the implementation of interactive multimedia and kit with Writing to Learn (WTL) strategies for hearing impairment students on the chemistry in daily life topics for junior high school. Interactive Multimedia and kit were implemented to 12 students junior high school with one group pretest-posttest design. The research instruments used were the observation on the use of interactive multimedia and the kit and test sheets. Data collection techniques are observation and tests analyzed descriptively. The Writing to Learn strategy component trained in this study is guided free writing, creative piece, and the end of class reflection. The results of the study showed that (1) interactive multimedia and kit implementation were a good and very good category, (2) the students' learning outcomes were increased after the learning, and (3) students' responses indicate that the interactive multimedia and kit response were positive.
\end{abstract}

Keywords: Interactive Multimedia, Kit, Writing to Learn Strategy, Hearing Impairment Student

\section{Introduction}

Science is a systematic study of nature and how nature affects the life and environment of humans. In the past, science was only defined as part of knowledge. Science also includes certain methods for finding and applying scientific knowledge that involves three main elements, which are science as attitude, science as process and science as a product [1]. To face the challenges of the present, intelligent and competitive Indonesian students need to be prepared that can be achieved through science education [2]. Science is a subject that is taught at Junior High School for Disabilities. Chemistry on the household is one of the topics that disabilities students, such as hearing impairment students, learned in Junior High School. This topic cannot be separated from students because it is attached to their daily life.

Hearing impairment students are students who have a problem in their hearing organs and effected in hearing impairments that could be ranged from mild level to heavy level. Hearing impairment students facing difficulties in their verbal/oral communication, both in terms of speaking and understanding other people's conversations, so it is difficult to communicate with the environment when people hear the usual use of verbal language as a communication tool [3]. Constraints in communication caused obstacles in the learning process of hearing 
impairment students. Hearing impairments inhibit students' communication activities due to limitations in language mastery, which results in difficulties in understanding complex sentences and interpreting abstract words[4].

Learning media is a tool that can stimulate students' thoughts, feelings, concerns and interests so that the learning process could be held [5]. Learning media should be able to provide motivation for students, stimulate students to remember what they have learned and made students give feedback and feedback [6]. Interactive multimedia is learning media that can support the delivery of knowledge to students, interactive multimedia is also useful in visualizing concepts, and interactive multimedia features can provide a clearer picture after students learn a concept [7]. Besides Interactive multimedia, Kit is also learning media, a series of test equipment for process skills in the science activity, equipped with a manual for its useful tools, produced and packaged in a unit box [8]. For disabilities students' learning process, teachers are expected to choose and determine the interesting learning media for the learning process to deliver lesson material in an effort to create innovative learning. In the learning process, the teacher does not only present one learning media. The presence of a variety of learning media will help students in interpreting the subject matter presented [9].

Student writing skills are important in the science classroom. Writing promotes criticalthinking skills and the construction of vital scientific concepts. [10] writing-to-learn assignments may provide effective ways of developing conceptual knowledge [11]. Writing-tolearn (WTL) strategy was useful for focusing on hearing impairment students on science concepts. The strategies in WTL are guide free writing, creative piece and the end of class reflections. In guided freewriting, students write their predictions, observation and conclusion about phenomena during science activity. Creative piece, students write their unique aspect of the science concepts. At the end of class reflections, students write about what they have learned in science activity [12].

Interactive multimedia and kit could be used as learning media for hearing impairment students. Interactive multimedia was proven to provide positive impacts for hearing impairment students[13]. The implementation of Interactive multimedia and kit is effective for hearing impairment students in science learning [14]. Using interactive multimedia could improving hearing impairment students' concept understanding [15].

Based on these descriptions, it is necessary to do research to know the effectiveness of the implementation of interactive multimedia and kit with the WTL strategy on chemistry on household topics for hearing impairment students on Junior High school for disabilities. The schools for this research are Pertiwi Junior High School for Disabilities, Mojokerto.

\section{Research Methodology}

The research method used in this research was One Group Pretest Posttest Design, an experiment conducted on one group only without any comparison group. The design of this method is:

$\mathrm{O}_{1} \mathrm{X} \mathrm{O}_{2}$

O1: Pretest before learning by using interactive multimedia and kit.

$\mathrm{X}$ : Treatment, learning by using interactive multimedia and kit.

O2: Posttest, after learning by using interactive multimedia and kit. [11] 
The objects of this research were 12 students of class VII Pertiwi Junior High School for disabilities. Data was obtained from the observation, test and questionnaire. Instruments that used in this research were observation sheet of interactive multimedia and kit implementations, learning outcomes test and students' responses questionnaire.

The data obtained from the observation sheet of interactive multimedia and kit implementation was described by an average score from two observers for each aspect and analyzed according to criteria as in table 1.

Table 1. Score Criteria.

\begin{tabular}{cc}
\hline Category & Value Scale \\
\hline Bad & $0-1,0$ \\
Enough & $1,1-2,0$ \\
Good & $2,1-3,0$ \\
Very good & $3,0-4,0$ \\
\hline
\end{tabular}

The data obtained then calculated by using the formula:

$$
\%=\frac{\text { total score of collecting data }}{\text { scoring criteria }} \times 100
$$

The scores were interpreted in Table 2.

Table 2. Interpreting score criteria.

\begin{tabular}{cc}
\hline Value Scale & Category \\
\hline $0 \%-20 \%$ & Very Bad \\
$21 \%-40 \%$ & Bad \\
$41 \%-60 \%$ & Enough \\
$61 \%-80 \%$ & Good \\
$81 \%-100 \%$ & Very good \\
\hline
\end{tabular}

Students' learning outcomes were analyzed to know students' conceptual understanding. Students' conceptual understanding were analyzed by calculating the test score with the following formula:

$$
\text { Score }=\frac{\text { Student's score }}{\max \text { score }} \times 100
$$

Students passed the minimum criteria score if the student' score $\geq 75$.

Questionnaire responses are given after the implementation and analyzed descriptively. The percentage of student questionnaire data was obtained based on the calculation of Guttman score scale in the following Table 3 below:

Table 3. Guttman Scale.

\begin{tabular}{cc}
\hline Answer & Score \\
\hline Yes & 1 \\
No & 0 \\
\hline
\end{tabular}

Students' responses were calculated by using this following formula: 


$$
\text { Percentage }(\%)=\frac{\text { total score }}{\text { criteria score }} \times 100
$$

Students' responses stated as positive if the percentage of student response is $>61 \%$.

\section{Results}

The observer used the observation sheet of interactive multimedia and kit implementations. There are four observers who observe four different groups. Student activities can be seen by observing several aspects of the WTL strategy. The WTL strategy aspects are the Free Writing Guide, Creative Piece and The End of Class Reflection. Guided Free Writing aspects include knowledge of experimental tools and materials, as well as experimental procedures. The Creative Piece aspect includes giving ideas and images. The End of Class reflection aspect includes reflecting student activities in rewriting the experimental procedure. The percentage of the effectiveness of each aspect is presented in the following table 4 and 5.

Table 4. Students` activities during interactive multimedia usage.

\begin{tabular}{clc}
\hline No & \multicolumn{1}{c}{ Aspect } & Percentage (\%) \\
\hline 1 & Navigation & 100 \\
2 & Concept & 100 \\
3 & Examples & 100 \\
4 & Guided Free Writing & 100 \\
5 & Creative Piece & 100 \\
6 & The End of Class Reflection & 100 \\
7 & Video & 100 \\
8 & Writing in box & 100 \\
9 & Matching picture & 100 \\
10 & Quiz & 100 \\
\hline
\end{tabular}

Based on Table 4, the student did all activities during learning using interactive multimedia. They had used navigation in interactive multimedia, read concept in material, saw examples of material, wrote an answer for each aspect in writing to learn strategy, watched the videos, wrote in box, matched the pictures and did a quiz for evaluation. All activities got $100 \%$.

Table 5. Students` activities during kit usage.

\begin{tabular}{clc}
\hline No & \multicolumn{1}{c}{ Aspect } & Percentage (\%) \\
\hline 1 & Students read the title of experiments & 87.5 \\
2 & Students read the objectives of experiments & 75 \\
3 & Guided Free Writing & 87.5 \\
& a. Students wrote tools and materials & 87.5 \\
& b. Students wrote Procedures of experiments & 75 \\
4 & Creative Piece & 87.5 \\
& a. Students giving ideas & 62.5 \\
& b. Students giving pictures
\end{tabular}




\begin{tabular}{lllc}
\hline No & \multicolumn{1}{c}{ Aspect } & Percentage (\%) \\
\hline & a. & Students finished the task & 75 \\
& b. & Students partly finished the task & 0 \\
& c. & Students didn't finish the task & 25 \\
\hline
\end{tabular}

Based on table 5, all activities got $>61 \% .87 .5 \%$ of students read the title of experiments, meaning that all students understood the title of the student activity sheets. In the aspect of the students read the objectives of experiments got a percentage of $75 \%$, there are some students still didn't understand the objectives of the experiments used. The Guided Free Writing aspects got a percentage of $87.5 \%$ which shows that students understood the aspects of Guided Free Writing, writing tools and materials, experimental procedures also. On the aspect of Creative Piece $75 \%$ of students able to express ideas, while $87.5 \%$ of students able to draw pictures, and $62.5 \%$ of students able to match some pictures. Students have been able to rewrite all procedures got a percentage of $75 \%$ while as many as $25 \%$ of students are not finished write partially on aspects of The End of Class Reflection.

In general, students make mistakes when typing in interactive multimedia or in student activity sheets. For example, students type in Bahasa "bawang putih" means "bawang putih", but it is still considered true by the observers. This is because each student has a different intelligence and ability to understand the information. The main factors affecting memory are background knowledge and the ability to organize information [16]. The level of disability and intelligence of hearing impairment students also affect the level of student memory. Using this media, it is expected that student achievement will increase according to the repetition they do [14].

Pretest of Students' Conceptual Understanding was done before limited trial of interactive multimedia and kit. Pretest and posttest consist of ten items multiple choices and five items of essays. Results of the pretest and posttest were shown on Table 6.

Table 6. Pretest and posttest score.

\begin{tabular}{cccc}
\hline No & $\begin{array}{c}\text { Student Initial } \\
\text { Name }\end{array}$ & Pretest Score & $\begin{array}{c}\text { Posttest } \\
\text { Score }\end{array}$ \\
\hline 1 & FH & 20 & 80 \\
2 & VM & 15 & 65 \\
3 & AH & 20 & 75 \\
4 & BR & 10 & 80 \\
5 & SR & 10 & 75 \\
6 & YPS & 10 & 75 \\
7 & HDPN & 15 & 60 \\
8 & NAN & 15 & 55 \\
9 & I & 25 & 60 \\
10 & G & 15 & 25 \\
11 & R & 0 & 10 \\
12 & MAF & 0 & 20 \\
\hline
\end{tabular}

Table 6 showed that pretest scores of all subjects were very low. In general, a student with a hearing impairment has normal or average intelligence. The intelligence development is affected by language development, hence hearing impairment children have below-average intelligence due to difficulty to understand verbal language [17]. The incompleteness of all subjects on the pretest was because of the lack of students' understanding of the concepts or their low memory about the concepts. Meanwhile, the students' posttest score increased than 
before, but there are four students aren't. That was because students had understood the concept that has been taught.

At the posttest, five subjects were complete and seven other subjects were still incomplete. The completeness of this score indicates that the subjects are FH, AH, BR, SR, and YPS learning well during learning using interactive multimedia and kits. They are actively working on student activity sheets and want to read the material in interactive multimedia. FH and BR got the highest score because they classified as a smart student. R and MAF students have the lowest posttest score because they cannot hear at all and have the lowest ability to speak. This makes it difficult to study as long as they can't do the posttest.

Overall students had been able to follow the learning process with a writing-to-learn strategy. Through students' understanding, students had been able to solve the problems. Interactive multimedia and kit with writing-to-learn strategies in hearing impairment students' can be well implemented and assessed to improve concept understanding [18].

After participating in the trial, the students were given a questionnaire response. Student questionnaire responses used to determine student responses to the interactive multimedia and kit that have been used. There are 11 aspects to the student response questionnaire. Student questionnaire response data were analyzed descriptively. In general, the student questionnaire responses were in a very feasible category.

Table 7. Students' responses.

\begin{tabular}{clc}
\hline No & \multicolumn{1}{c}{ Aspect } & $\begin{array}{c}\text { Percentage } \\
(\%)\end{array}$ \\
\hline 1. & Do you feel happy using the interactive multimedia and kit? & 100 \\
2. & Is the presentation of interactive multimedia and kit good? & 92 \\
3. & Are the sentences easy to understand? & 100 \\
4. & Are the tasks easy to do? & 92 \\
5. & Are the experiment procedures easy to do? & 67 \\
6. & Are the font types and font sizes ease you to read? & 88 \\
7. & Are the pictures help you to understand the concepts? & 92 \\
8. & Are the pictures help you to complete the experiment procedures? & 92 \\
9. & Are the pictures help you in making some product ideas? & 92 \\
10. & Are the interactive multimedia and kit ease you to do group & 75 \\
& activity? & 75 \\
11. & Do you want to redo the experiments at home? & \\
\hline
\end{tabular}

Based on table 7 , every aspect gots a positive response because it got a percentage of $\geq$ $61 \%$. In the question of "Do you feel happy using the interactive multimedia and kit and Are the sentences easy to understand?" got $100 \%$, the highest percentage. The language used in interactive multimedia used language as simple as possible so that it is easily understood by hearing impairment students. During learning, students looked very excited when asked to read the material or work on the problems. Interactive multimedia and student activity sheet present pictures with colorful frames so as to improve students' learning motivation.

In the question "experiment procedures easy to do?" got $67 \%$ that the lowest percentage. Practical activities in student activity sheets are easy to do, only get a percentage of $67 \%$. This is showed that practicum in student activity sheet is not easy to do, this may be caused by the use of a stove when practicum makes the students feel scared. Overall, interactive multimedia and kits got positive responses from students. The results of the response are good because in the process of imitating the scientific method, hearing impairment students learn in groups, 
conduct experiments, and interpret information so that it is in accordance with the results of [19].

\section{Conclusion}

The observation of interactive multimedia and kit implementation was a good and very good category. The students' learning outcomes were increased after learning. The results of students' responses indicate that the interactive multimedia and kit response were positive.

Acknowledgments. The writer like to thank DRPM (Direktorat Riset dan Pengabdian Masyarakat) that fund this research, LPPM Unesa, FMIPA, and Headmaster and all of the stakeholder of Junior High School.

\section{References}

[1] Ibrahim, Muslimin.: Dasar-dasar Proses Belajar Mengajar. Surabaya: Unesa University Press. (2010)

[2] Liliasari.: Pembelajaran Sains Untuk Membangun Insan Indonesia Cerdas dan Kompetitif. Prosiding Seminar Nasional Pendidikan (hal 1-10). Bandar Lampung: FKIP Universias Lampung. (2009)

[3] Purwaningsih, Dwi Ratna and Dwi Sulisworo.: Pengembangan Lembar Kerja Siswa (LKS) Bagi Anak Berkebutuhan Khusus (Tuna Rungu) SMK Kelas X Pokok Bahasan Suhu Dan Termometer. Prosiding Pertemuan Ilmiah XXIX HFI Jateng \& DIY. (2015)

[4] Suparno.: Komunikasi Total. Yogyakarta: Institut Keguruan dan Ilmu Pendidikan Yogyakarta. (2001)

[5] Sadiman, Arief. S.: Media Pendidikan: Pengertian, Pengembangan dan Pemanfaatannya. Jakarta: PT Raja Grafindo Persada. (2012)

[6] Mais, Asrorul.: Media pembelajaran anak berkebutuhan khusus. Jember: CV Pustaka Abadi. (2016)

[7] Teoh, B.S.P \& T.K. Neo. (2007). Interactive Multimedia Learning: Students' Attitudes and Learning Impactin an Animation Course. The Turkish Online Journal of Educational Technology TOJET, 6(4):1303-6521. 2007. [Online]. Available: http://www.tojet.net/articles/v6i4/643.pdf. [15 September 2019]

[8] Ahmadi, Linda, dkk.: Pemanfaatan Alat KIT Pada Pembelajaran IPA Di Kelas IV SDN 1 Telaga Kabupaten Gorontalo. Gorontalo: Jurnal Program Studi PGSD, Fakultas Pendidikan, dan Pemanfaatannya. Universitas Negeri Gorontalo.(2015)

[9] Direktur Jenderal Pendidikan Dasar Dan Menengah.: Peraturan Direktur Jenderal Pendidikan Dasar dan Menengah Nomor : 10/D/Kr/2017 Tentang Struktur Kurikulum, Kompetensi Inti, Kompetensi Dasar, dan Pedoman Implementasi Kurikulum 2013 Pendidikan Khusus. Jakarta: Direktur Jenderal Pendidikan Dasar Dan Menengah. (2017)

[10] Baker, William P, et. al.: Writing-to-Learn in the Inquiry-Science Classroom: Effective Strategies from Middle School Science and Writing Teachers. The Clearing House: A Journal of Educational Strategies, Issues and Ideas. (2010)

[11] McNair, Lisa and Chris Venters.: Work in Progress: Using Writing-to-Learn Methods to Improve Conceptual Knowledge in Engineering Statics. 2012 Frontiers in Education Conference Proceedings. (2012) 
[12] Lang, Harry G. And John A. Albertini.: Constrution of Meaning in the Authentic Science Writing of Deaf Students. Journal of Deaf Studies and Deaf Education 6:4 Fall 2001. (2001)

[13] Riza, Lala Septem, et.al.: A Concept and Implementation of Instructional Interactive Multimedia For Deaf Students Based On Inquiry-Based Learning Model. Journal of Engineering Science and Technology Vol. 13, No. 7 (2018) 2016 - 2035. (2018)

[14] Sukarmin, Sri Poedjiastoeti, Dian Novita and Achmad Lutfi.: Effectivity of Interactive Multimedia and Student Activity Sheets with Writing-To-Learn (WTL) Strategy in Science Learning for Hearing Impairment Students. Proceedings of the Seminar Nasional Kimia - National Seminar on Chemistry (SNK 2018). (2018)

[15] Poedjiastoeti, Sri dan Liliasari.: "Pembelajaran Kimia Berbantuan Multimedia Untuk Siswa Tunarungu SMALB-B”. Jurnal Ilmu Pendidikan. Jilid 17 (1): pp. 55-63. (2010)

[16] Slavin, Robert E.: Psikologi Pendidikan Teori dan Praktik Edisi Kedelapan Jilid 1. Jakarta: Indeks. (2008)

[17] Somad, Permanarian. and Herawati, Tati.: Ortopedagogik Anak Tunarungu. Jakarta: Depdikbud. (1995)

[18] Poedjiastoeti, Sri.: Kit Kimia dengan Strategi Writing-to-learn untuk Siswa SMALB Tunarungu. Prosiding Seminar Nasional Kimia Unesa 2012, pp. B179-B188. (2012)

[19] Pinto-Silva, F. E., Martins, P. R. S., \&Rumjanek, V. M.: Rousing Interest in Science among Secondary School Deaf Students. Scholarly Journal of Scientific Research and Essay (SJSRE) Vol 2(7), pp. 104-108. (2013). [Online]. Available : http://scholarlyjournals.com/sjsre/archive/2013/July/pdf/Pinto-Silva\%20et\%20al.pdf. (2019) 